УДК 332.81:365.4

DOI https://doi.org/10.32838/2663-6468/2019.3/19

\title{
Кучеренко О.Ю.
}

Національна академія державного управління при Президентові України

\section{СТРАТЕГІЇ Й РЕЗУЛЬТАТИ ДЕРЖАВНОЇ ЖИТЛОВОЇ ПОЛІТИКИ В УКРАЇНІ}

\begin{abstract}
У статті здійснено історичний аналіз стратегічних иілей і результатів житлової політики в Україні з погляду темпів житлового будівництва й забезпечення громадян житлом відповідно до положень Конституиії. Сформульована основна проблема житлової сфери: можлива невідповідність між потребою в житлі як у предметі першої необхідності та недостатністю або відсутністю можливостей ї̈ задоволення окремою людиною, соиіальною групою або суспільством загалом, що вимагає державного регулювання й перерозподілу необхідних ресурсів. В умовах низької платоспроможності громадян установлено прямий взаємозв'язок між рівнем державної присутності в житловому секторі та поліпшенням житлового забезпечення. Разом із тим показана необхідність раціонального залучення до житлового будівництва коштів платоспроможних громадян. Визначено такі проблеми, що потребують аналізу й вирімення на загальнодержавному та місиевому рівнях: оцінювання стану жситлового фонду й накопичених потреб у його оновленні, повної вартості домоволодіння й утримання житла, платоспроможності домогосподарств щодо житлового самозабезпечення, формулювання відповідної стратегії державної політики в жситловій сфері та інструментів ії реалізації.
\end{abstract}

Ключові слова: держава, політика, стратегія, житло, будівництво, забезпечення.

Постановка проблеми. Законодавство багатьох країн містить положення щодо державної житлової політики та стратегій іiі реалізації. Так, право на житло й роль держави в житловому забезпеченні громадян визначені ст. 47 прийнятої в 1996 році Конституції України, де сказано, що держава створює умови, за яких кожний громадянин матиме змогу побудувати житло, придбати його у власність або взяти в оренду. Громадянам, які потребують соціального захисту, житло надається державою та органами місцевого самоврядування безоплатно або за доступну для них плату відповідно до закону [1].

Сучасна державна житлова політика суттєво змінила попередню стратегію житлового забезпечення громадян. Так, ст. 44 Конституції СРСР 1977 року проголошувала, що громадяни мають право на житло, яке забезпечується розвитком та охороною державного і громадського житлового фонду, сприянням кооперативному й індивідуальному житловому будівництву, справедливим розподілом під громадським контролем жилої площі, яка надається в міру здійснення програми будівництва упорядкованих помешкань, а також невисокою платою за квартиру й комунальні послуги. При цьому громадяни повинні дбайливо ставитися до наданого їм житла [2].

Сучасна державна житлова політика в Україні, обравши стратегію підтримки приватної власності на житло, містить, на наш погляд, протиріччя між короткостроковими цілями та довгостроковими результатами й наслідками реалізації положень чинної Конституції. Якщо забезпечення житлом у процесі майже безоплатної приватизації 1990-х років виглядало як державний «подарунок» для мешканців квартир, то придбання нового житла й вартість житлово-комунальних послуг особливо після 2015 року стали розглядатися як непосильний тягар для більшості домогосподарств. При цьому основна частина неминучих необхідних витрат на подальше придбання, утримання й ремонти будинків громадянами ще не усвідомлена, адже відповідний складник у тарифах і статистична інформація були і є відсутніми. За умови іiі урахування власне житло, про яке йдеться в Конституції, може стати для більшості громадян недоступним.

Виникає необхідність перегляду або уточнення положень державної житлової політики і стратегій iii реалізації з огляду на необхідність належного утримання будинків, оновлення житлового фонду й гарантування сталого забезпечення громадян житлом.

Аналіз останніх досліджень i публікацій. У вітчизняній науковій літературі політика і стратегії держави у житловій сфері, організаційно-фінансові питання житлового будівництва, утримання житлового фонду досліджувалися в докторських 
дисертаціях В. Божанової [3], Д. Левчинського [4], Ю. Манцевича [5], О. Непомнящого [6], Н. Олійник [7], В. Омельчука [8 ], К. Паливоди [9].

Указані автори в основному зосереджувалися на окремих організаційних і фінансових проблемах забезпечення більшої доступності житла й пошуках відповідних механізмів їх вирішення 3 використанням зарубіжного досвіду. Попри корисність пропонованих часткових поліпшень схем фінансування, шляхів здешевлення вартості житла, допомоги окремим категоріям населення, проблема принципової можливості задоволення житлових потреб усіх громадян на засадах положень Основного Закону та чинних стратегічних документів і законодавства щодо власності на житло, ролі держави тощо безпосередньо не ставилася й залишається невирішеною.

На особливу увагу заслуговує монографія В. Кравченка, К. Паливоди, В. Поляченка, де вдало відмічена основна проблема житлової сфери - протиріччя між потребою в житлі як у предметі першої необхідності та недостатністю або відсутністю можливостей iї задоволення окремою людиною, соціальною групою або навіть суспільством загалом, що вимагає активної ролі держави [10, с. 137]. Виходячи із цього, автори в загальних рисах намітили специфіку прояву житлової проблеми в Україні. Це - помилкова схема здійсненої приватизації, самоусунення держави від розв'язання житлової проблеми, загальне скорочення фінансування та спад обсягів житлового будівництва, невиконання затверджених державних програм житлового будівництва, висока зношеність житлових будинків і відставання з капітальними ремонтами, низька якість благоустрою житла та висока енергоємність, відсутність ринкових інструментів регулювання в житловій сфері, корупція й тіньова економіка в земельних питаннях.

У вказаній роботі справедливо зазначається, що більшість громадян України є неплатоспроможною на ринку житла, як первинному, так і вторинному. Водночас автори не подають рекомендацій щодо необхідної за цих умов ролі й місця держави в житловому забезпеченні громадян на стратегічну перспективу.

Перші спроби розширення та поглиблення поглядів на проблему житлового забезпечення громадян в Україні можна знайти в новітніх публікаціях В. Ніколаєва [11], Т. Ніколаєвої [12], П. Пантелеєва [13], А. Щербини [14], де вказується на ії̈ зв'язок із власністю на житло.

Але загальним недоліком досліджень усіх вітчизняних авторів і фахівців з близького зару- біжжя є використання порівнянь із розвиненими країнами та намагання адаптувати їхні готові стратегії й механізми. На нашу думку, вказана вище основна проблема житлової сфери має різні вирішення залежно від того, на якому рівні усуспільнення та за якими стандартами можливе належне житлове забезпечення громадян. Тому досвід держав, де більшість громадян за рівнем доходів здатна до самозабезпечення житлом за високими стандартами (США, країни $\mathrm{CC}$ ), не може бути зразком для України та інших країн, де навіть набагато нижчі стандарти житлового забезпечення недосяжні для більшості неплатоспроможних домогосподарств і вимагають значного усуспільнення володіння житловим фондом i перерозподілу коштів на його утримання. Це тягне за собою необхідність дослідження багатьох суміжних питань: стану будинків та оцінювання відтермінованих величезних потреб у капітальних ремонтах, вартості ефективного домоволодіння, формування відносин власності на житло, визначення реальних стандартів житлового забезпечення, юридичних механізмів трансформації власності тощо.

Постановка завдання. Виходячи 3 того, що державна житлова політика в Україні конституційно проголошує права на житло й відповідні державні зобов'язання, завданням статті $€$ історична систематизація різних стратегій держави щодо іiі ролі в житловому забезпеченні громадян на різних історичних етапах та аналіз їх результатів задля можливого визначення нових стратегічних цілей $\mathrm{i}$ завдань в умовах, що склалися в Україні.

Виклад основного матеріалу дослідження. Історичний екскурс. Як відомо, після соціалістичної революції 1917 року в Україні та загалом у СРСР здійснено усуспільнення приватного житла й розпочато його масове щільне заселення в містах переселенцями із сільської місцевості. Нове будівництво майже не здійснювалося. Квартирна плата була скасована.

У 20-х роках у період непу набули поширення різні форми власності на житло, зокрема й житлово-будівельні кооперативи. В умовах децентралізації та загального браку коштів забудовників забудова велася малоповерховими будинками. Згодом були створені державні фонди позик для підтримки житлового будівництва, відновлена диференційована плата за житлово-комунальні послуги. Але потреби в житлі для здійснення масштабної індустріалізації за допомогою чинного тоді механізму житлового будівництва залишалися все ж не задоволені. 
У 1930-ті роки була здійснена централізація житлового будівництва й житлово-комунального господарства в союзно-республіканських міністерствах. Кооперативи були ліквідовані. Активна державна участь 3 метою директивно встановленого підвищення забезпеченості житлом до рівня санітарногігієнічної норми 8,25 кв. м на особу та розселення багатосімейних квартир дала змогу до 1940-го року збільшити міський житловий фонд у 2,3 рази.

Друга світова війна залишила лише в Україні без домівок 10 млн громадян. За статистикою, німецькі війська знищили цілком і сильно поруйнували 714 міст, 28 тис. сіл, понад 2 млн. будинків (близько 38 млн кв. м житлової площі - 50\% довоєнного фонду) [15]. Тому в повоєнні роки розгорнулося особливо інтенсивна відбудова малоповерхового державного житла. До кінця 1950-х років велося і спорудження нових недовговічних дво-, триповерхових будинків найпростіших форм 3 місцевих будівельних матеріалів. За десять повоєнних років загалом по СРСР відбудовано 300 млн кв. м житла, або в 1,5 рази більше, ніж увесь житловий фонд дореволюційної Росії [10, с. 44]. Така забудова становить тепер незначну частину наявного житлового фонду.

Але забезпеченість житлом усе ж залишалася низькою. Тому наприкінці 1950 -х років державою був узятий новий стратегічний курс на інтенсивне індустріальне житлове будівництво з метою забезпечення кожної сім’ї окремою квартирою, на відміну від попередніх цілей щодо збільшення норми площі. Для здешевлення житла були зменшені деякі норми.

Для розселення комунальних квартир почали індустріально зводилися п'ятиповерхові житлові будинки, які були розраховані на 25-30 років експлуатації, хоча 3 технічного боку могли слугувати 75 і більше років. Площа таких будівель сягає сьогодні 72 млн кв. м і в загальному обсязі житлового фонду різних міст України становить 10-40\%. Завдання житлового будівництва того періоду вирішувалися завдяки застосуванню великоблочних i великопанельних конструкцій житлових будинків, спорудження житла великими масивами із застосуванням методів поточного будівництва. За 10 років по СРСР так покращили житлові умови 120 млн осіб, або більше ніж половина населення. 31940 по 1970 роки житловий фонд зріс у 4 рази, а забезпеченість житлом досягла 11 кв. м на особу.

Поряд із державним розвивалося й кооперативне житлове будівництво, частка якого сягнула понад 20 млн кв. м, або майже чверті від введеної в 1960-х роках площі. Будівництво кооперативних будинків здійснювалося державними підрядними організаціями за державними нормами й цінами. Земельні ділянки під забудову з мережами водогону, каналізації, електропостачання виділялися безкоштовно. Членам житлово-будівельних кооперативів надавався практично безвідсотковий кредит у розмірі 60-70\% вартості будівництва 3 терміном погашення 15-20 років.

Здійснювалася й державна підтримка будівництва відомчого житла підприємствами. У 1960 році країна посідала перше місце у світі за обсягами житлового будівництва: 14 квартир на 1 тис. населення проти 10,7 квартир у другій за обсягами будівництва країни - ФРН [16, с. 7].

У містах понад 100 тис. мешканців було заборонене індивідуальне будівництво [10].

Отже, у період економічного зростання державі вперше вдалося значну частку потреб у житлі задовольнити за рахунок особистих коштів громадян, коштів підприємств, а також зняти із себе функцію подальшого утримання відповідного житла.

У подальшому державна стратегія інтенсивного будівництва житла в 1970-1980-і роки була спрямована на забезпечення нормативних потреб у житловій площі - 13,65 кв. м на особу. Міста забудовувались 9-, 12- й більшої поверховості великопанельними будинками на вільних, віддалених від центрів міст територіях. Будинки, зведені в той період, відрізнялися від п'ятиповерхових більшою комфортністю, але мали багато недоліків: передусім їх теплоізоляційні характеристики були приблизно у 2-3 рази нижчі за європейські норми. Нормативні терміни експлуатації таких будинків до капітального ремонту становили 25-30 років.

Активна державна житлова політика дала змогу до 1985 року довести середню забезпеченість житловою площею загалом по країні до 14,6 кв. м на особу, надати окремі квартири більше як $80 \%$ міського населення.

Але виникли нові потреби в капітальному ремонті довоєнного та післявоєнного фонду. Недостатньо використовувалися можливості децентралізованого та індивідуального житлового будівництва.

У середині 1980-х років було започатковану програму «Житло-2000», яка мала на меті довести забезпеченість житловою площею до 22,5 кв. м на особу за рахунок багатоповерхового будівництва, а також залучення коштів підприємств і кооперативів.

Останніми роками «перебудови» вперше намітилося гальмування введення житла (таблиця 1). 
Таблиця 1

Житлове будівництво в Україні перед здобуттям незалежності

\begin{tabular}{|c|c|c|c|c|c|c|c|}
\hline \multirow{2}{*}{ Показник } & \multicolumn{7}{|c|}{ Роки } \\
\cline { 2 - 8 } & $\mathbf{1 9 8 5}$ & $\mathbf{1 9 8 6}$ & $\mathbf{1 9 8 7}$ & $\mathbf{1 9 8 8}$ & $\mathbf{1 9 8 9}$ & $\mathbf{1 9 9 0}$ & $\mathbf{1 9 9 1}$ \\
\hline Уведено житла, млн кв. м & 19,2 & 20,4 & 21,3 & 20,9 & 19,5 & 17,5 & 14,5 \\
\hline
\end{tabular}

Джерело: [7]

Таблиця 2

Житлове будівництво в незалежній Україні

\begin{tabular}{|c|c|c|c|c|c|c|c|}
\hline Роки & $\begin{array}{c}\text { Уведено } \\
\text { житла, } \\
\text { млн кв. м }\end{array}$ & Роки & $\begin{array}{c}\text { Уведено } \\
\text { житла, } \\
\text { млн кв. м }\end{array}$ & $\begin{array}{c}\text { Частка } \\
\text { державного } \\
\text { фінансування }\end{array}$ & Роки & $\begin{array}{c}\text { Уведено } \\
\text { житла, } \\
\text { млн кв. м }\end{array}$ & $\begin{array}{c}\text { Частка } \\
\text { державного } \\
\text { фінансування }\end{array}$ \\
\hline 1992 & 14,1 & 2000 & 5,6 & 1,5 & 2009 & 6,4 & 1,7 \\
\hline 1993 & 12,3 & 2001 & 5,9 & 1,9 & 2010 & 5,0 & 0,3 \\
\hline 1994 & 10,1 & 2002 & 6,1 & 2,2 & 2011 & 7,2 & 0,8 \\
\hline 1995 & 8,7 & 2003 & 6,4 & 4,3 & 2012 & 10,8 & 0,7 \\
\hline 1996 & 6,8 & 2004 & 7,6 & 2,5 & 2013 & 11,2 & 0,5 \\
\hline 1997 & 6,4 & 2005 & 7,8 & 3,6 & 2014 & 9,7 & 0,3 \\
\hline 1998 & 5,8 & 2006 & 8,6 & 2,8 & 2015 & 11,0 & 0,5 \\
\hline 1999 & 6,1 & 2007 & 10,2 & 1,6 & 2016 & 9,4 & 0,3 \\
\hline
\end{tabular}

132014 року без урахування тимчасово окупованої території АР Крим, м. Севастополя та зони проведення антитерористичної операції. Це ускладнює подальший аналіз в абсолютних цифрах. Тому у відповідних порівняннях далі нами інколи використовуватимуться дані до 2014 року.

Джерело: Держстат Украӥни

Криза в державі не давала змоги здійснювати житлове будівництво в необхідних масштабах порівняно 3 іншими країнами. Для досягнення показника 28-30 кв. м на особу в 1990 році було вирішено подвоїти обсяги житлового будівництва, але на нових стратегічних засадах: диверсифікації й децентралізації джерел фінансування та кредитування пільгового оподаткування, заохочення індивідуального будівництва, відведення земельних ділянок на правах користування, розпорядження й успадкування, формування державного та суспільного житлового фонду, прогресивної квартплати за надлишки житла.

Житлове будівництво в незалежній Україні переведено на ринкові рейки, тобто його обсяги стали визначатися не стільки соціальною (житловою) політикою держави, яка в принципі відсутня, скільки демографічними процесами, урбанізацією і платоспроможним попитом громадян за обмеженого використання, як потім виявилося, недосконалих фінансово-кредитних механізмів.

У щорічних витратах на житлове будівництво частка державного та місцевих бюджетів знижувалася і стала становити менше ніж 1\% (таблиці 2, 3).

Почала здійснюватися масова, практично безоплатна приватизація квартир із нечітко визначе- ним володінням багатоквартирними будинками, що призупинило процес їх ремонту.

Порівнявши показники введення площ на 1000 осіб в Україні та в інших пострадянських республіках, можемо констатувати, що очевидним стало наше відставання (рис. 1).

Значною мірою це викликане саме низьким рівнем участі держави в безпосередньому фінансуванні житлового будівництва або в підтримці програм доступного житла (у 2017-2018 роках: Білорусь $-25,2 \%$, Росія - 5,4\%, Казахстан - 17\%). В Україні за рахунок коштів державного бюджету у 2016 році (останні опубліковані дані) прийнято в експлуатацію 30,3 тис. кв. м загальної площі житла (0,3\% від загального обсягу), що на 42,3\% менше за рівень 2015 року. За середньої площі збудованих квартир цього достатньо лише для 365 сімей.

Державні програми були практично згорнуті.

На нашу думку, натепер досягнуто граничні фінансові можливості громадян щодо фінансування житлового будівництва за наявних недосконалих фінансових механізмів і високих процентних ставок причому з урахуванням наявності в них початкових активів у вигляді приватизованих квартир, адже специфічний механізм фінансування нового житлового будівництва в Україні 


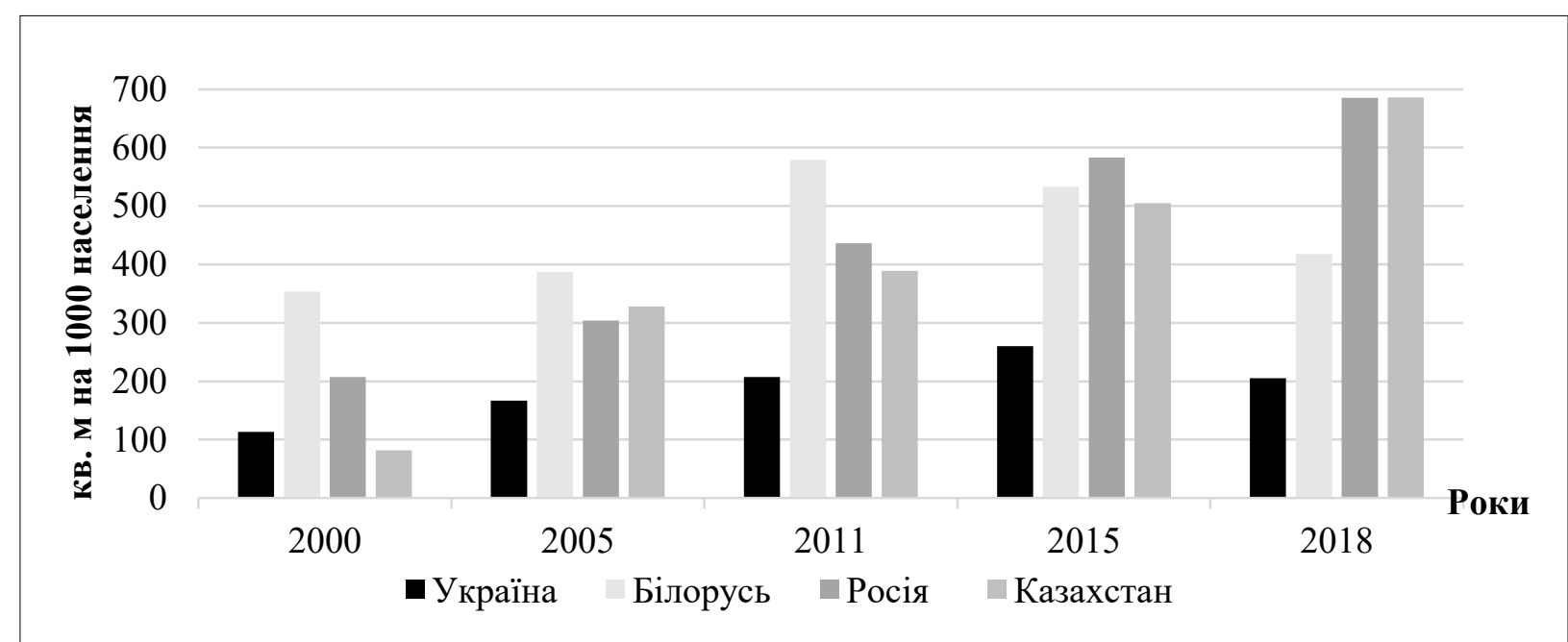

Рис. 1. Уведення в експлуатацію житла в Україні та деяких країнах СНД

Джерело: побудовано автором на основі державної статистики відповідних краӥн

Таблиця 3

Індекси цін на житло у 2016-2018 рр., \%

\begin{tabular}{|l|c|c|c|c|c|c|}
\hline & \multicolumn{3}{|c|}{ Первинний ринок житла } & \multicolumn{3}{c|}{ Вториний ринок житла } \\
\cline { 2 - 7 } & 2016 & 2017 & 2018 & 2016 & 2017 & 2018 \\
\hline Усього & $\mathbf{1 0 2 , 1}$ & $\mathbf{1 0 4 , 4}$ & $\mathbf{1 0 5 , 1}$ & $\mathbf{1 0 3 , 4}$ & $\mathbf{1 0 6 , 2}$ & $\mathbf{1 0 8 , 0}$ \\
\hline Квартири однокімнатні & 99,7 & 106,0 & 103,7 & 111,4 & 109,2 & 106,9 \\
\hline Квартири двокімнатні & 105,2 & 103,4 & 105,0 & 100,2 & 106,1 & 108,8 \\
\hline Квартири трикімнатні & 100,3 & 103,1 & 108,1 & 101,6 & 103,8 & 108,1 \\
\hline
\end{tabular}

Джерело: Держстат України

полягає фактично не у придбанні, а в розширенні площ - використанні безкоштовно отриманого в результаті приватизації житла для часткової оплати нового, що треба ураховувати під час оцінювання майбутнього платоспроможного попиту. Іншою причиною скорочення темпів будівництва житла є відносне зниження платоспроможності населення порівняно 3 вартістю придбання й утримання житла (таблиці 3,4 ).

Так, якщо 32003 по 2017 роки сукупні ресурси середнього домогосподарства зросли у 14,7 разів, то ціни на житлово-комунальні послуги та паливо - у 19,2 рази (ураховуючи безготівкові пільги та субсидії у складі сукупних ресурсів домогосподарств).

Уважається, що нормальний попит на житло в країні може бути підтриманий, коли середньомісячна зарплата сягає рівня ціни 1 кв. м житла. За даними ж Держстату України, середня зарплатня на початок 2019 року становила 8865 тис. грн, а ціна одного квадратного метра житла у столиці 25 тис. грн, а в регіонах 10-20 тис. грн, тобто в кілька разів менше. За індексом доступності житла Україна посідає одне з останніх місць у світі (залежно від джерел інформаціі).
Отже, можна констатувати, що саме в результаті зменшення державного фінансування та державної підтримки житлового забезпечення вразливих верств обсяги житлового будівництва скоротились у два-три рази порівняно 3 кінцем 80 -х років.

Показовим для аналізу скорочення попиту на нові помешкання є завищена вартість житлового будівництва в умовах нерозвинених і непрозорих ринкових відносин (таблиця 5).

Так, статистика 2018 року свідчить, що 53247 млн грн капітальних інвестицій у житлові будівлі будівельні роботи становили 29345 млн грн, або 55\%, а введено 8,7 млн кв. м житла, тобто 1 кв. м інвесторам обійшовся у 6120 грн, а будівельникам - у 3373 грн. У 2016 році з 42503 млн грн капітальних інвестицій вартість безпосередньо будівельних робіт становила 18012 млн грн, або $42 \%$. За ці кошти введено в експлуатацію загалом 9,367 млн кв. м житла, у тому числі 8,341 млн кв. м, або майже 90\%, новозбудованого. Отже, загалом 1 кв. м інвесторам коштував 4500 грн, а будівельникам - 1900 грн. У 2010 році відповідні вартості становили загалом 3000 грн і 800 грн. При цьому ціни на житло є значно вищими, що мало б свідчити про високу прибутковість будівництва. 
Таблиця 4

Платоспроможність домогосподарств

\begin{tabular}{|l|c|c|c|c|c|c|c|c|c|c|c|c|c|c|}
\hline & 2004 & 2005 & 2006 & 2007 & 2008 & 2009 & 2010 & 2011 & 2012 & 2013 & 2014 & 2015 & 2016 & 2017 \\
\hline $\begin{array}{l}\text { Сукупні } \\
\text { ресурси домо- } \\
\text { господарства: } \\
\text { тис. грн. мі. } \\
\text { динаміка, \% }\end{array}$ & 0,912 & 1,321 & 1,612 & 2,012 & 2,893 & 3,015 & 3,481 & 3,854 & 4,145 & 4,471 & 4,563 & 5,231 & 6,238 & 8,165 \\
\hline $\begin{array}{l}\text { Індекс } \\
\text { спож. цін }\end{array}$ & 112,3 & 110,3 & 111,6 & 116,6 & 122,3 & 112,3 & 109,1 & 104,6 & 99,8 & 100,5 & 124,9 & 143,3 & 112,4 & 113,7 \\
\hline $\begin{array}{l}\text { Індекс цін } \\
\text { у житловому } \\
\text { будівництві }\end{array}$ & 124,7 & 122,1 & 124,1 & 126,4 & 129,3 & 107,8 & 116,6 & 118,2 & 109,5 & 104,8 & 111,1 & 124,6 & 108,3 & 115,0 \\
\hline $\begin{array}{l}\text { Індекс цін на } \\
\text { ЖКП і паливо }\end{array}$ & 107,2 & 114,6 & 166,5 & 112,3 & 128,2 & 108,2 & 113,8 & 111,0 & 100,7 & 100,3 & 134,3 & 203,0 & 147,2 & 110,6 \\
\hline $\begin{array}{l}\text { Пільги } \\
\text { та субсидії } \\
\text { безготівкові } \\
\text { на ЖКП, \% }\end{array}$ & 0,9 & 0,5 & 0,6 & 0,7 & 0,5 & 0,6 & 0,6 & 0,6 & 0,6 & 0,4 & 0,4 & 1,3 & 4,7 & 4,7 \\
\hline
\end{tabular}

Джерело: Держстат Украӥни

Таблиця 5

Вартісні показники житлового будівництва

\begin{tabular}{|l|c|c|c|c|}
\hline Роки & $\begin{array}{c}\text { Капітальні інвестиції } \\
\text { у житлові будівлі, } \\
\text { млн грн }\end{array}$ & $\begin{array}{c}\text { Обсяг виконаних } \\
\text { будівельних робіт, } \\
\text { млн грн }\end{array}$ & $\begin{array}{c}\text { Прийнято в } \\
\text { експлуатацію житла, } \\
\text { всього, млн кв. м }\end{array}$ & $\begin{array}{c}\text { Прийнято } \\
\text { в експлуатацію нового } \\
\text { житла, млн кв. м }\end{array}$ \\
\hline 2010 & 25754 & 6876 & 8,6 & 8,1 \\
\hline 2014 & 33177 & 11292 & 9,7 & 8,8 \\
\hline 2015 & 45610 & 13908 & 11,0 & 9,8 \\
\hline 2016 & 42503 & 18012 & 9,4 & 8,3 \\
\hline 2017 & 53372 & 23730 & 10,2 & 10,2 \\
\hline 2018 & 53247 & 29345 & 8,7 & 8,7 \\
\hline
\end{tabular}

Джерело: Держстат України

Таблиця 6

Чисті збитки підприсмств будівництва

\begin{tabular}{|c|c|c|c|c|c|c|c|c|c|c|c|}
\hline Роки & $\mathbf{2 0 0 8}$ & $\mathbf{2 0 0 9}$ & $\mathbf{2 0 1 0}$ & $\mathbf{2 0 1 1}$ & $\mathbf{2 0 1 2}$ & $\mathbf{2 0 1 3}$ & $\mathbf{2 0 1 4}$ & $\mathbf{2 0 1 5}$ & $\mathbf{2 0 1 6}$ & $\mathbf{2 0 1 7}$ & $\mathbf{2 0 1 8}$ \\
\hline Збитки, млрд. грн & 7,98 & 4,44 & 5,10 & 4,58 & 1,00 & 5,89 & 27,95 & 25,86 & 1,30 & 5,0 & - \\
\hline
\end{tabular}

Джерело: Держстат України

Водночас, як не дивно, у всі роки незалежності підприємства будівництва за статистикою були збитковими (таблиця 6).

Отже, врегулювання економічного механізму в житловому будівництві, зокрема ціноутворення та обліку, може дещо змінити ситуацію на ринку житлової нерухомості.

За часи незалежності на початок 2019 року в Україні введено близько 0,23 млрд кв. м нового та реконструйованого житла. За статистичними даними 2017 року, вже без АР Крим та зони АТО площа житлового фонду становить 984,8 млн кв. м.

Попри значний спад у житловому будівництві й незадовільний стан житлового фонду, середня статистична забезпеченість житлом усе ж зростає за раху- нок зменшення чисельності населення. Так, із 1980 до 2017 роки вона зросла на 13,3 кв. м. (таблиця 7).

Але варто враховувати й великі відмінності в житлових умовах сімей при нормі 13,65 кв. м житлової площі на особу (таблиця 8). Так, 38,4\% домогосподарств займають площу менше за вказану норму.

Структура кількості житлових будинків за роками побудови та класами сформувалася дуже несприятливо 3 позицій сьогоднішніх проблем їх утримання мешканцями (таблиці 9, 10, 11, 12).

У 2012 році нараховувалося 10150252 будинки, у 2013 році - 10169123, у 2014 році - 10147185 , а у 2015 році - 9082907, 2016 році - 9113051, 2017 році - 9130197, 2018 році - 9137304. 
Середньостатистична забезпеченість житлом громадян України

\begin{tabular}{|l|c|c|c|c|c|c|}
\hline Роки & $\mathbf{1 9 8 0}$ & $\mathbf{1 9 9 0}$ & $\mathbf{2 0 0 0}$ & $\mathbf{2 0 1 0}$ & $\mathbf{2 0 1 5}$ & $\mathbf{2 0 1 7}$ \\
\hline Кв. м на особу & 14,0 & 17,8 & 20,7 & 23,3 & 22,9 & 23,3 \\
\hline Динаміка & - & 3,8 & 2,9 & 2,6 & $-0,4$ & 0,4 \\
\hline
\end{tabular}

Джерело: Держстат України

Таблиця 8

Забезпечення домогосподарств житловою площею

\begin{tabular}{|c|c|c|c|}
\hline \multirow{2}{*}{$\begin{array}{c}\text { Житлова площа } \\
\text { у 2017 році }\end{array}$} & Усі домогосподарства & Міські & Сільські \\
\cline { 2 - 4 } & $\mathbf{1 4 9 3 4 , 9}$ & $\mathbf{1 0 ~ 0 6 1 , 3}$ & $\mathbf{4 ~ 8 7 3 , 6}$ \\
\hline \multicolumn{3}{|c|}{ За розміром житлової площі на одну особу, \% } \\
\hline до $7,5 \mathrm{~m}^{2}$ & 9,1 & 11,1 & 5,2 \\
\hline $7,5 \mathrm{~m}^{2}-9,0 \mathrm{M}^{2}$ & 5,0 & 5,4 & 3,9 \\
\hline $9,1 \mathrm{M}^{2}-13,65 \mathrm{~m}^{2}$ & 24,7 & 26,4 & 69,2 \\
\hline понад $13,65 \mathrm{M}^{2}$ & 61,2 & 57,1 & 69,7 \\
\hline
\end{tabular}

Джерело: [17]

Таблиця 9

Розподіл будинків за роками побудови (станом на початок 2011 рік)

\begin{tabular}{|c|c|c|c|c|}
\hline \multirow{2}{*}{ Роки } & \multicolumn{2}{|c|}{ Усього } & \multirow{2}{*}{ Міста } & \multirow{2}{*}{ Села } \\
\cline { 2 - 5 } & Одиниць & $\%$ & 4055394 & 6104242 \\
\cline { 2 - 5 } & 10159636 & 100 & 264879 & 204447 \\
\hline до 1919 & 469326 & 4,6 & 441633 & 756234 \\
\hline $1919-1945$ & 1197867 & 11,8 & 969947 & 1582251 \\
\hline $1946-1960$ & 2552198 & 25,1 & 902251 & 1542816 \\
\hline $1961-1970$ & 2445067 & 24,1 & 625800 & 1020122 \\
\hline $1971-1980$ & 1645922 & 16,2 & 465846 & 626728 \\
\hline $1981-1990$ & 1092574 & 10,8 & 385038 & 371644 \\
\hline
\end{tabular}

Джерело: [18] (останні опубліковані дані)

Таблиця 10

Розподіл будинків за класами й терміном служби

\begin{tabular}{|c|c|c|c|c|c|c|c|c|}
\hline Класи & 1 & 2 & 3 & 4 & 5 & 6 & & \\
\hline \multicolumn{2}{|c|}{ Термін служби, років } & 150 & 125 & 100 & 100 & 70 & $30-50$ \\
\hline Усього & одиниць & 10159636 & 77007 & 285326 & 758148 & 2787344 & 3250099 & 3001712 \\
\hline & $\%$ & 100 & 0,1 & 2,9 & 7,6 & 27,5 & 32,1 & 29,8 \\
\hline Міста & \multicolumn{2}{|c|}{4055394} & 37298 & 170886 & 396180 & 1201282 & 1251939 & 997809 \\
\hline Села & \multicolumn{2}{|c|}{6104242} & 39709 & 114440 & 361968 & 1586062 & 1998160 & 2003903 \\
\hline
\end{tabular}

Джерело: [18] (останні опубліковані дані)

Таблиця 11

\section{Сдиний класифікатор житлових будинків}

\begin{tabular}{|c|l|}
\hline Класи & \multicolumn{1}{|c|}{ Характеристики } \\
\hline 1 & $\begin{array}{l}\text { Особливо капітальні будинки з кам’яними або цегляними стінами (товщина в 2,5-3,5 цеглини), із залі- } \\
\text { зобетонним чи металевим каркасом, із залізобетонним перекриттям, висотою приміщень від полу до } \\
\text { стелі 3,0 метра й вище, 3 повним складом інженерного обладнання, в яких строк експлуатації не пере- } \\
\text { вищує 50\% терміну служби або виконано капітальний ремонт }\end{array}$ \\
\hline 2 & $\begin{array}{l}\text { Капітальні будинки із цегляними стінами (товщина в 1,5-2,5 цеглини), із залізобетонним перекриттям } \\
\text { висотою приміщень від полу до стелі 2,7-3,0 метра, з повним складом інженерного обладнання, в яких } \\
\text { строк експлуатації не перевищує 50\% терміну служби або виконано капітальний ремонт }\end{array}$ \\
\hline
\end{tabular}


Закінчення таблиці 11

\begin{tabular}{|c|l|}
\hline Класи & \multicolumn{1}{|c|}{ Характеристики } \\
\hline 3 & $\begin{array}{l}\text { Будинки великопанельні, великоблочні та з місцевих будівельних матеріалів (цегла, дрібні блоки з при- } \\
\text { родного чи штучного каменю тощо) (термін служби - 100 років), із залізобетонним перекриттям (збірне } \\
\text { чи монолітне), висотою приміщень від полу до стелі 2,5-2,7 метра, 3 повним складом інженерного } \\
\text { обладнання, в яких строк експлуатації не перевищує 50\% терміну служби }\end{array}$ \\
\hline 4 & $\begin{array}{l}\text { Будинки великопанельні, великоблочні та з місцевих дрібноштучних будівельних матеріалів (цегла, дрібні } \\
\text { блоки з природного і штучного каменю тощо, із залізобетонним або дерев'яним перекриттям, висотою } \\
\text { приміщень від полу до стелі 2,5 метра, в яких строк експлуатації перевищує 50\% терміну служби }\end{array}$ \\
\hline 5 & $\begin{array}{l}\text { Будинки зі стінами з монолітного шлакобетону, шлакоблоків, черепашника та інших дрібноштучних } \\
\text { виробів із місцевої сировини, із залізобетонним чи дерев’яним перекриттям, висотою приміщень від } \\
\text { полу до стелі 2,5 метра }\end{array}$ \\
\hline 6 & $\begin{array}{l}\text { Будинки зі стінами полегшеної конструкції - збірно-щитові, каркасно-засипні, каркасно-камишитові, } \\
\text { глинобитні, дерев’яні (рублені чи брусчаті) тощо }\end{array}$ \\
\hline
\end{tabular}

Джерело: [19]

Таблиця 12

Розподіл домогосподарств за помешканнями різних років забудови

\begin{tabular}{|l|c|c|c|}
\hline \multicolumn{1}{|c|}{ Роки } & Усі домогосподарства & Міські & Сільські \\
\hline до 1950 року & 7,3 & 6,2 & 16,5 \\
\hline у 1950-х роках & 11,4 & 8,9 & 25,7 \\
\hline у 1960-х роках & 21,7 & 19,8 & 21,5 \\
\hline у 1970-х роках & 24,5 & 26,0 & 18,2 \\
\hline у 1980-х роках & 24,5 & 27,5 & 7,8 \\
\hline у 1990-х роках & 8,7 & 9,1 & 2,2 \\
\hline після 2000 року & 2,3 & 2,4 & \\
\hline
\end{tabular}

Джерело: [18]

Таблиця 13

Обладнання житла

\begin{tabular}{|c|c|c|c|c|c|}
\hline \multirow{2}{*}{ Роки } & \multicolumn{5}{|c|}{ Питома вага загальної площі, обладнаної } \\
\cline { 2 - 6 } & водопроводом & каналізацісю & $\begin{array}{c}\text { центральним } \\
\text { опаленням }\end{array}$ & газопостачанням & $\begin{array}{c}\text { гарячим } \\
\text { водопостачанням }\end{array}$ \\
\hline 1995 & 50,5 & 47,3 & 47,9 & 79,9 & 35,0 \\
\hline 2000 & 54,2 & 51,4 & 52,8 & 81,9 & 38,6 \\
\hline 2005 & 56,2 & 53,8 & 56,2 & 82,6 & 40,0 \\
\hline 2010 & 59,6 & 57,5 & 62,1 & 83,2 & 43,1 \\
\hline 2015 & 60,8 & 58,8 & 68,7 & 83,3 & 47,0 \\
\hline 2016 & 61,2 & 59,2 & 68,9 & 83,1 & 47,0 \\
\hline 2017 & 61,8 & 59,8 & 69,1 & 83,1 & 47,5 \\
\hline
\end{tabular}

Джерело: Держстат Украйни

Загальний житловий фонд масово постарішав, а значна його частина досягла граничних термінів служби або термінів проведення капітальних ремонтів і реконструкції.

Так, довоєнна та повоєнна забудова до початку 1980 -х років $(81,8 \%)$, досягала віку нормативного проведення капітальних ремонтів, що, однак, зважаючи на постійні фінансові проблеми в Україні, не здійснено. Легко бачити, що в тій чи іншій формі реновації потребують не менше ніж 80\% будинків. 3 іншого боку, відсоток домогосподарств, які потерпають від наднормативної зношеності їхніх будинків, становить $64,9 \%$.
Крім того, значна частина житла морально застаріла, не обладнана тими чи іншими зручностями й також потенційно потребує модернізації, виходячи 3 європейських стандартів якості житла (таблиця 13).

Отже, спад обсягів житлового будівництва, настання критичного віку більшої частини наявного житлового фонду й низька якість помешкань створили серйозну проблему стійкого житлового забезпечення громадян України. У подальшому дві тенденції: скорочення населення та хвиля вибуття зношеного житла - будуть взаємодіяти в різних напрямах, але з часом, на нашу думку, переважатиме все ж вибуття житлового фонду, 
що не дає змоги залишити процес, некерованим державою.

Висновки. Сучасна ситуація зі станом житлового фонду і платоспроможністю переважної частини населення Україні свідчить, з одного боку, про необхідність переорієнтації на стратегію відбудови й оновлення наявного житлового фонду, а з іншого боку, про необхідність посилення ролі держави в цьому процесі.

Для вироблення конкретних стратегій щодо фінансових джерел і юридичних механізмів та
3 огляду на масштабу проблеми, треба оцінити спроможність окремих груп власників квартир, організацій співвласників будинків, а також громад, держави, приватних інвесторів утримувати, експлуатувати й відтворювати житло.

Треба також мати на увазі й потреби в оновленні комунальної інфраструктури, адже відповідні капітальні витрати, як і в житлі, лягають на споживачів, громаду або державу та приватних інвесторів. Указані завдання формують напрями подальших досліджень.

\section{Список літератури:}

1. Конституція України. URL: http://www.president.gov.ua/documents/constitution (дата звернення: 06.05.2019).

2. Конституция CCCP. URL: http://constitution.garant.ru/history/ussr-rsfsr/1977/red_1977/1549448 (дата звернення: 06.05.2019).

3. Божанова В.Ю. Организационно-экономический механизм повышения доступности жилья для населения. Днепропетровск: Наука и образование, 2007. 392 с.

4. Левчинський Д.Л. Державне регулювання інвестиційного процесу відтворення житлового фонду: автореф. дис. ... докт. екон. наук: спец. 08.00.03. Запоріжжя: Класич. приват. ун-т, 2012. 40 с.

5. Манцевич Ю.М. Соціально-економічні проблеми розвитку житлового господарства України і стратегія його удосконалення: монографія. Київ: Профи-Информ, 2007. 388 с.

6. Непомнящий О.М. Методологічні засади формування та реалізації державної житлової політики: автореф. дис. ... докт. наук з держ. упр.: спец. 25.00.02. Донецьк: Донец. держ. ун-т упр., 2013. 36 с.

7. Олійник Н.І. Державне регулювання ринку житла в Україні: дис. ... докт. наук. з держ. управл.: спец. 25.00.02. Київ: НАДУ, 2011. 391 с.

8. Омельчук В.А. Державне регулювання ринку доступного житла в Україні: дис. ... докт. екон. наук: 08.00.03 «Економіка та управління національним господарством». Київ: НДЕI, 2012. 422 с.

9. Паливода К.В. Грошові ресурси та фінансові механізми капітального інвестування у житлове будівництво: автореф. дис. ... докт. екон. наук: 08.00 .08 «Економіка та управління національним господарством». Київ. Б.в. 2010.38 с.

10. Кравченко В.І., Паливода К.В., Поляченко В.А. Основи житлової економіки. Київ: Основа, 2007. 416 с.

11. Ніколаєв В. Специфічні умови формування нової житлової політики в Україні. Публічне управління та публічна служба в Україні: стан проблем та перспективи розвитку: матеріали Науково-практичної конференції за міжнародною участю (7-8 вересня 2018 р., м. Київ) / за заг. ред. В.С. Куйбіди, М.М. Білинської, В.Л. Федоренка. Київ: Ліра-К, 2018. С. 319-321.

12. Ніколаєва Т.В. Фінансово-економічний механізм утримання і відтворення житлового фонду в умовах трансформації відносин власності. Науковий вісник Національного університету державної податкової служби України. Серія «Економіка, право» / наук. ред. П.В. Мельник. Київ: НУДПСУ. 2012. № 1 (56). С. 81-85.

13. Пантелеєв П.О. Інвестиційний процес утримання житлових будинків. Формування ринкових відносин в Україні. 2013. № 11. С. 108-112.

14. Ніколаєв В.П., Щербина А.А. Модель ринку житла і житлово-комунальних послуг з урахуванням платоспроможності споживачів. Будівельне виробництво: міжвідомчий наук.-техн. зб. Київ: НДІБ, 2017. № 63/3. С. 34-41.

15. Енциклопедія сучасної України / редкол. І.М. Дзюба та ін. Київ, 2004. Т. 3: Біо-Бя. 696 с.

16. Жилищное строительство в СССР. Состояние и перспективы развития. Москва: Госстройиздат, 1962. $204 \mathrm{c}$.

17. Діти, жінки та сім’я в Україні: статистичний збірник / Держстат України. Київ, 2018. 320 с.

18. Житловий фонд України у 2010 році / Держстат України. Київ, 2011. 376.

19. Про затвердження Єдиного класифікатора житлових будинків залежно від якості житла та наявного інженерного обладнання: Наказ Державного комітету будівництва, архітектури та житлової політики України від 30 вересня 1998 року № 215. URL: https://www.gioc.kiev.ua/files/File/215_1998.htm (дата звернення: 06.05.2019). 


\section{СТРАТЕГИИ И РЕЗУЛЬТАТЫ ГОСУДАРСТВЕННОЙ ЖИЛИЩНОЙ ПОЛИТИКИ В УКРАИНЕ}

В статье осуществлен исторический анализ стратегических иеелей и результатов жилищной политики в Украине с точки зрения темпов жилищного строительства и обеспечения граждан жильем в соответствии с положениями Конституции. Сформулирована основная проблема жилищной сферы: возможное несоответствие между потребностью в жилье как в предмете первой необходимости и недостаточностью или отсутствием возможностей ее удовлетворения отдельным человеком, соииальной группой или обществом в целом, что требует государственного регулирования и перераспределения необходимых ресурсов. В условиях низкой платежеспособности граждан установлена прямая взаимосвязь между уровнем государственного присутствия в жилищном секторе и улучшением обеспечения жильем. Вместе с тем показана необходимость рачионального привлечения в жилищное строительство средств платежеспособных граждан. Определены следующие проблемы, требующие анализа и решения на общегосударственном и местном уровнях: оценка состояния жилищного фонда и накопленных потребностей в его обновлении, полной стоимости домовладения и содержание жилья, платежеспособности домохозяйств по жилищному самообеспечению, формулировка соответствующей стратегии государственной политики в жилищной сфере и инструментов ее реализации.

Ключевые слова: государство, политика, стратегия, жилье, строительство, обеспечение.

\section{STRATEGIES AND RESULTS OF THE STATE HOUSING POLICY IN UKRAINE}

The article presents a historical analysis of the strategic goals and results of housing policy in Ukraine in terms of the rates of housing construction and provision of housing for citizens in accordance with the terms of the Constitution. The main problem of the housing sector is formulated: the possible mismatch between the need for housing as a necessity and the lack of opportunities for its satisfaction by an individual, social group or society as a whole, which requires state regulation and redistribution of necessary resources. In conditions of low solvency of citizens, there is a direct relationship between the level of state presence in the residential sector and the improvement of housing provision. At the same time, the necessity of rational attraction of solvent citizens to housing construction is shown. The following problems require analysis and solution at the national and local levels: assessment of the housing stock and the accumulated needs for its renewal, the full cost of housing and housing, households solvency in terms of housing self-financing, formulation of an appropriate strategy of public policy in the housing sector and its instruments realization.

Key words: state, politics, strategy, housing, construction, provision. 